\title{
JUAN DE TORRES'S POETICS OF VISION: “OIOSQUEYANOVESQUE”*
}

\author{
Louise M. Haywood \\ Trinity Hall, University of Cambridge \\ lmh37@cam.ac.uk \\ Desire] is neither limited to nor satisfied by its objects, but is the \\ energy that leads human society to develop its own form. \\ Northrop Frye ${ }^{\mathrm{I}}$
}

\begin{abstract}
In this article, I examine Juan de Torres's poetics of the visual through a reading of his Cancionero de Palacio dealing with the visual sphere. I argue that his poetry demonstrates familiarity with medieval scholastic psychology, particularly in relation to sight and memory. The visual sphere can be understood as both the external, phenomenological and somatic world of experience and intersubject interaction, and as the interior world of the psyche and the affect. Lacanian and Jamesonian reading strategies are deployed to approach latent psychological and socio-political content in Torres's representation of the psychic disarray of the lover. The visual sphere is the medium by and through which desire is apprehended and the subject inscribes itself in the symbolic order, seeks the desire of
\end{abstract}

* The title phrase derives from marginalia at the foot of fol. $89^{\mathrm{v}}$ of the Cancionero de Palacio (Salamanca, Biblioteca Universitaria, ms 2653; Dutton's SA7), plausibly test strokes possibly in a later hand. Compositions on fol. $89^{\mathrm{v}}$ form part of a group in which poems by Álvaro de Luna and dovetail into a series of compositions by Juan de Torres. I give manuscript sigla and composition identificaction numbers from Dutton with Krogstad (1990-9I). The research presented here was originally carried out as part of Leverhulme Research Project Grant, ref. F/oo 025/AV, "The Culture of Spanish Verse in the Late Middle Ages", directed by Prof. D. S. Severin (Liverpool). Many thanks to the anonymous readers for their constructive input.

${ }^{I}$ See Frye (1957, p. 73); I encountered this particular quotation out of context apud Jameson (I989, p. 7I). Jameson (pp. 68-74) approves Frye's attempts to establish a level of analysis that relates the individual literary text to the social through desire but critiques his failure to "restore a perspective in which the imagery of libidinal revolution and of bodily transfiguration once again [as it did in medieval four-fold exegesis] becomes a figure for the perfected community", (p. 74). Also see Frye (I957, pp. 7I-I30). 
the Other and is subject to the surveying gaze of power hierarchies. Torres's work shows great skill and wit, and stands as a particularly good example of the way in which a highly abstract poetic corpus deals directly with the visual understood as power and hierarchy.

\section{Keywords}

Juan de Torres, Visual Sphere, Scholastic Psychology, Political Unconscious.

\section{Resumen}

El presente artículo examina una gama de obras de Juan de Torres del Cancionero de Palacio en que el vate trata un temario que engloba el campo visual. En las obras bajo consideración Torres recurre a la teoría de las facultades o potencias del alma según la psicología escolástica, sobre todo en su relación con el sentido de la vista y la memoria. El campo visual abarca tanto el mundo externo, fenomenológico y somático de interacciones intersubjetivas como el interno del ánimo y los sentimientos. Uso las ópticas lacaniana y jamesoniana para explicar el contenido psicológico latente y socio-político de la representación de la confusión anímica del yo-lírico. El campo visual es el medio por el cual se percibe el deseo y el sujeto se inscribe en el orden simbólico, busca el deseo del Otro y es sujeto a la vigilancia del poder. La poética de Torres manifiesta con gran destreza y cierto tono humorístico la manera en que una poesía con alto grado de abstracción trata directamente con el campo visual como registro de poder y jerarquía.

\section{Palabras claves}

Juan de Torres, Campo visual, Psicología escolástica, Inconsciente político.

Juan de Torres is author of some 38 compositions, 34 of which are uniquely attested in Cancionero de Palacio (Salamanca, Biblioteca Universitaria, ms 2653; Dutton with Krogstad's SA7), where they appear in two blocks as well as interspersed among the writings of his contemporaries. ${ }^{2}$ Although little known now, Torres's work was clearly held in high regard by his immediate peers, likely the court circle of the Constable of Castile, Don Álvaro de Luna, as well as being respected beyond this immediate network. ${ }^{3}$ Although certainly active in the I430s

\footnotetext{
${ }^{2}$ Here I refer only to Torres's SA7 poems.

${ }^{3}$ Tentative comments made by Haywood (2009), now appear more likely in the light of the findings of Mosquera Novoa's 20I5 doctoral dissertation. Unfortunately, various sections of thesis's
} 
(Mosquera Novoa, 20I5, p. 86), his work continued to circulate into the early sixteenth century, being attested in a factitious manuscript of that date. ${ }^{4}$ Given his relatively commonplace name, attempts to identify him have occasionally confused several distinct figures and precise identification may never be possible; however, Lucía Mosquera Novoa's careful conclusions, in the most recent study of the question, are convincing:

El perfil del poeta que dibujan los textos me ha llevado a plantear la posibilidad de que estemos ante un caballero noble, procedente de los Torres de Soria y relacionado con la corte castellana, cuya vida itinerante le permitiría entrar en contacto con las distintas cortes Trastámara y, además, conocer las varias tradiciones poéticas de las que se nutre en su obra. (20I4, p. 522)

In my reading, Juan de Torres's Palacio poetry clusters around three common cancionero themes: sight, absence and knowledge. ${ }^{5}$ A very rough count, including only the most explicit references, is that 27 of the 35 Palacio poems refer at least one of the themes. Twenty refer to sight, thirteen each to absence and knowledge, and only eight to none. Of those invoking more than one of these themes, only five use all three, nine refer to two, and thirteen to one.

Although he makes no specific allusion to received late medieval theories of vision, as does Juan de Mena in his Coronaçión (Dutton ID or56; discussed Burke, 2000, p. I3; Folger, 200I, pp. 63-65), Torres does refer clearly and explicitly to the functions of the faculties. As I shall show here, the visual field is a core element in his poetics through which he examines the relationship between the lover and the beloved with use of the related tropes of absence and knowledge. The manifest content of the poetry is expounded in relation to the constitution

on-line version have been suppressed, pending publication; the critical edition (for Alessandria: Edizioni dell'Orso, 20I6) appeared too late to be cited here and a separate study is planned. I thank Prof. Cleofe Tato and Dr. Lucía Mosquera Novoa (both A Coruña) for this information and providing me with materials.

${ }^{4}$ Biblioteca de la Universidad de Salamanca, MS 2763, Dutton sigil SAro; Torres's composition appears in the first portion, SAroa, dated c. I495 (Dutton-Krogstad, I990-9I, VII, p. 663), with the two parts bound together dated c. I520 (Beltrán, I999, p. 46).

"Mosquera Novoa's section on "El Coracón, los ojos, el Amor" (2015, pp. I87-195) is unavailable on-line; however, its summary in the dissertation's conclusion suggests she has located some of these motifs in non-peninsular traditions (2015, pp. 523-24). Rodado Ruiz discusses sight and its relation to other sense organs and the faculties of the lover's soul and dedicates a section her monograph to the motif of absence (2000, pp. 47-75, 86-89 \& I47-49); for reasons of space I do not discuss her findings in details here. 
of the subject in scholastic psychology, as urged by Giorgio Agamben (1993). It is treated as functioning first on a courtly level, concealing a carefully controlled erotic latent content (see Macpherson and Tillier both 1985; discussed below). The presence of such erotic content means that Torres's poetry straddles different conceptions of love, drawing —as will be seen- on the naturalism amoroso more strongly associated in the first half of the fifteenth century with the learned tradition, on faculty psychology and on the tenets of amor hereos, particularly in depicting the psychic diminishment of the lover. ${ }^{6}$ However, Torres's staging of a poetics of vision projects and exposes a social and political horizon. To approach articulations of the social and political, reading strategies are adapted from the structuralist Marxian perspective advocated by Frederic Jameson (1989) and, in keeping with the accent on the visual sphere, filtered through Lacanian psychoanalysis rather than the Freudian perspective espoused by Agamben (1993). ${ }^{7}$ James F. Burke (2000), E. Michael Gerli (2000, 20II) and Robert Folger (2009, pp. 3236) have each used Lacanian psychoanalysis balanced with a thorough grounding in medieval faculty psychology and moral philosophy as a hermeneutic tool to prise open socio-political readings of late fifteenth-century sentimental romance and Fernando de Rojas's Celestina whilst elsewhere I have applied a similar optic to Juan Ruiz's Libro de Buen Amor (Haywood, 2008). With them, I hold not only that we should "always consider the views of theorists from the period when discussing matters having to do with the operations of the consciousness" (Burke, 2000 , p. I) but also "use the conceptual apparatus of (post)-modern theories of subjectivity in order to trace (to make present the absence of) the non-articulated implications and over-determinations of premodern reflections of the self and its manifestations in literary texts" (Folger, 2009, p. 4I).

Although Jameson recognises the analytical power of psychoanalytical reading strategies, particularly in the Lacanian mode, he does so with regard to a more strictly psychoanalytical than literary critical approach and emphasizes that it performs on the level of the individual subject analogously to the operations

${ }^{6}$ On naturalism amoroso and its link to learned contexts see Cátedra’s pioneering 1989 study; Toro Pascua (1994) uses Guevara's Sepultura de Amor (c.I464) to explore its presence in the poetry of Enrique IV's court circle. Amor hereos, love as a morbid mental pathology related to faculty psychology and somatic ill health, are discussed in Wack's analysis of Constantine the Africa's Viaticum (1990) and its commentaries, by Toro Pascua (1994), and Folger (2002 and 2009).

7 There is insufficient space to discuss Lacanian psychoanalytical models in detail here. Several aspects of his break from Freudian approaches make his approach particularly suited to the medieval period; see Kay (200I), Gaunt (200I, esp. pp. 500-50I, and 2004), Holsinger (2005), and Haywood (2008, pp. I3, I32-I33). 
of Marxist literary theory to his notion of political unconscious - that is, the registration in textual material of competing ideologies (in his terms, "sign systems of modes of production" [p. 98]) of whose presence its author may be unaware- and the totality. ${ }^{8}$

Rather than follow a strictly Marxian view to demystify literature as a servant of a particular mode of production, a Jamesonian optic defocuses the dialectic or diachronic analysis to view it instead as a "field of force" registering "the dynamics of sign systems of several distinct modes of production". As such literary works are formal structures carrying messages in their own right (1989, p. 98) and thus are socially symbolic. Jameson's method serves here since it permits an examination of what he terms a text's "political unconscious" to offer an exegetical method capable of extrapolating through manifest and latent content - that is courtly, erotic and psychoanalytical readings - to the socially symbolic where antagonisms and contradictions in their context of production are registered. Jameson's method offers a particularly fitting optic for early fifteenth-century Iberian cultural products due to the climate of profound intellectual, social and political change and tension.

The Jamesonian structuralist-Marxian approach consists of a threefold exegesis on the levels (Jameson uses the terms "phases" and "horizons") of the political, the social and the historical, which he envisages as three concentric rings. Jameson's objects are modern narrative texts, which he aligns with Northrop Frye's horizons of romance (1957, pp. 7I-I30), rather than lyric poetry, the object here.' The first phase of analysis, the political, reads the narrative as a symbolic act (in the structural socio-anthropological sense) that reveals "what the text represses" (Jameson, 1989, p. 48) and brings to light fissures or contradictions in the ideological system or systems of which it forms a part but which are not (necessarily) realised on the surface of the text. Within the late nineteenth and early twentieth-century novel, romance work (like dream work) functions in the plot (pp. 76-77) to construct a magical resolution for irresolvable contradictions for the individual which are simply cancelled or ignored in relation to the social. On the social horizon, the hermeneutic of desire (a wished for resolution) resides not in the individual but in the body as a figure for community so the narrative acts like a parole (a single utterance) within a broader langue (system of possibilities for expression) of class discourse to articulate "the smallest intelligible unit of the

${ }^{8}$ On totality, see Jameson (1989, pp. 50-57, 190-194 and 284), and Hardt \& Weeks (2000, pp. 2I-22). It may be regarded as the synchronic suprastructural system of the mode of production.

9 The threefold Jamesonian system is lucidly expounded by Fry (2010). 
essentially antagonistic collective discourses of social classes" (I989, p. 76; also see pp. 87-88). The historical phase of analysis folds back to reveal the text reconfigured - Jameson acknowledges that, in a sense, this is a rewriting (pp. 94-95) — to display competing ideologies.

Jameson emphasizes that his proper object is narrative since the political phase is immanent in plot (pp. 76-77). Despite this, as I understand it, in his conclusion Jameson advocates his critical methodology as appropriate for adaptation to other cultural artefacts. Lacanian psychoanalytical techniques are a useful bridge from literary critical to socio-political analysis because his work allows us to grasp how socialization and entry into language bring a subject into a place in hierarchically structured social orders that impose subjection in various registers. ${ }^{10}$ I here attempt to use it as an optic for exploring the social and political horizons of Juan de Torres's courtly poetry. In short, my approach grows from the conviction that a close textual reading grounded in contemporaneous aesthetics and philosophy reveals the manifest content but that other techniques are necessary to recover latent content and the social and political horizons of the poetic work.

Sight was held to be a dynamic process in which pneuma (lit. breath) was sent along the optic nerve out through the eye to the external world, a process known as extramission. "Pneuma, psychic or animal spirit, was understood to be a form of warm air (the combination of the elements of fire and air), vital to life, and which, for example, flowed through the arteries to permit communication between the internal organs, the soul and the brain. Pneuma carried species, or image-replicas, of the objects apprehended back along the same route to the forebrain, known as intromission, where they were presented to and processed by the functions of the soul's faculties residing in or around the ventricles of the brain. By the fourteenth century, accounts of vision tended to favour a model oriented more towards intromission (Folger, 2009, pp. 44-45).

Various models concerning the number and relationship of the faculties and ventricles, and the precise processes involved in seeing were in circulation (Green, 2003; Agamben, 1993), consequently, I present in what follows only the most widely received (Carruthers, I990, p. 52, Tascioglu \& Tascioglu, 2005). Senseimages are first presented to the frontal lobes where resides the sensus commu-

Io I return to explore this further on a future study on the dream vision poetry of Palacio; see Gaunt (200I, particularly pp. 505-506, n. 64).

II For a detailed assessment of medieval visual theory, particularly in relation to the Iberian peninsula, see Burke (2000, pp. I2-30). See also Haywood (2008), and Folger (2009). 
nis (common sense) and where they are sorted by the representational faculties: imaginativa and fantasia, the repository of previously apprehended images and sensations and the engine for their potential recombination into the new, respectively. Objects and sensations are then subject to interpretation and cognition by the potentia aestimativa in the medial ventricle. Finally, the third, posterior, cell is the seat of the mnemonic functions, the storehouse of processed cognition, with which —occasionally - will or movement is associated.

The medical paradigms at the root of this conceptualization used spatial and visual images to convey the structure of the psyche: the ventricles are described as temple chambers, little bags or pockets, treasuries, and so forth, and the threadlike connections between the two frontal lobes and the medial ventricle were described as worms, vermis. Although such descriptions have their origin in early surgical manuals, it is imperative to realise that Galen, Hippocrates and their disciples are necessarily using descriptive, metaphorical language both to describe the physical structures of the brain and to map the functions of the soul onto the body as material phenomena. These same divergent metaphorical models come to inform non-scientific discussions of the soul, mind and body. Mary Carruthers, for example, notes that the Aristotelian tradition favoured the heart, over the brain, as primary organ involved in mnemonic processes. Although this view was overturned medically by the Alexandrine schools, metaphoric use of heart as seat of memory continued, as is borne witness by the medieval etymology of Latin revocari, "to call back" and recordari, "to recollect" (I990: 47-60), from whence Castilian recordar, "to remember, recall".

The depiction of the heart as seat of emotion is a commonplace of court love poetry, which occurs repeatedly in Torres's oeuvre where its relation to scholastic psychology can be discerned. Torres's "Coraçón, deves saber" (ID2587, SA7-206; Palacio, pp. 197-198) is a dialogue between the lover and his heart. ${ }^{12}$ Humorously, the lover reminds the organ, "senyor", that he shares its suffering and berates it for deceiving him about what it has desired to see: today causes sadness since the lady seen cannot be she whom his heart has praised so highly. Here the heart functions metonymically for the faculties of the soul that process and store senseimages whilst the lyric persona speaks as the potentia aestimativa (cognition), evaluating total past experience (the heart's desire to see the beloved) against experiential reality, only to find it wanting.

${ }^{12}$ All citations from Torres's oeuvre are from Palacio 1993 unless otherwise stated; page numbers are given at first reference. 
Torres's grasp of scholastic psychology appears also in his references to other faculties. In "Non me basta discreçión" (ID2588, SA7-207; Palacio, p. 198), the faculty of discreçión, "wisdom and understanding", is insufficient to understand how peace, folgura, may be achieved since the lyric persona considers the desired end impossible and endures the madness of continued service to one who cares not. In "Departa en toda partida" (ID245I, SA7-6I; Palacio, p. 46) Juan de Torres deploys one of his favoured figures - syllepsis by metonomy - to personify the lyric persona's heart and have it stand also for the lover himself. ${ }^{\mathrm{I} 3} \mathrm{In}$ all of these compositions, Torres's personification and address of his heart as the seat of emotion stands in metonymy for the lyric persona, revealing his awareness of the relationship between the body and the faculties of the soul.

My contention in what follows is that Torres's courtly poetry - as well as much other cancionero poetry often described in modern readings as highly abstract and conceptual and frequently viewed with distaste - is fundamentally organized around sight. That a poetry almost devoid of visual imagery should be structured around vision will undoubtedly sound paradoxical, perhaps even impossible, to many modern readers who lament the absence of concrete imagery but I suggest that the visual correlates as much to an external and phenomenological world, a "generalized visual field", as it does to the internal space of the brain whence intromission is projected, where the psychomachia of the potencies and faculties is enacted and where memory resides. In other words, imaginative (psychic) experience is also, and by necessity, somatic and social, or - at the very least - performative. ${ }^{\mathrm{I} 4}$ As Robert Folger observes, "Through gestures, clothing, manners, behaviour, acts and words appropriate to his rank, the nobleman must evoke the appearance which determines the essence" (2009, pp. 58-59), including staking a claim to existimatio, public esteem, through poetic composition (pp. 50-62).

${ }^{13}$ Syllepsis and related figures of brevitas, such as synecdoche and metonomy, are frequent in Torres's poetry. Casas Rigall (I995, pp. 134-I36) describes two types of syllepsis, each consisting of three operations. In the first type, something inanimate is personified (tongue), then comes by synecdoche or metonymy to represent an abstract concept (eloquence), then by synecdoche represents the lover or beloved. In the second, an abstract concept is personified (desire), it is then or also used in its literal sense before, by metonymy, standing for the lover. I shall refer to these as synecdochal syllepsis and metonymic syllepsis, respectively.

${ }^{14}$ This external world is Burke's "communal visual field", a "generalized, choric visual field that encodes within it the precepts of the symbolic order" (2000, 2I-25, at pp. 2I and 25, respectively), the subject's acceptance of his/her entry into language, power structures and a relation with the laws that govern behaviour in all areas. Also see Folger's "choric phantasmatic field" (2009, esp. pp. 49-52 \& 55-59). 
In relation to Torres, I shall argue that the mediation of the love relationship through sight (and sometimes also hearing) as primary sense(s) stands as a canvas on to which are projected anxieties about power and recognition. ${ }^{\text {I5 }}$ It is important to stress here that both senses were regarded in this period as strongly analogous in psychic function, such that auditory impressions are translated into images or impressions in the mind (see, for example, Burke, 2000, pp. 79-8I). To depict an amatory relationship in such terms - where the spiritual and psychic internal world of the faculties, senses and affect find a corollary in the somatic and external worlds - is to stage it in a public arena, to permit the ostensibly private to become (bodily) display and to allow a homology to develop between internal and external through their mediation or folding over upon one another; a homology which is already present in the use of concrete and spatial imagery to depict the operations of the potencies, as discussed above.

Torres's poetry shows an explicit awareness of the public nature of the lover's gaze in the courtly context. His song, “¿Qué será de mí, cuytado?” (ID2597, SA7217; Palacio, p. 203), vividly presents the danger residing in the public nature of looking and the gaze:

¿Qué será de mí, cuytado?

Pues non miro vuestr'asseo, que, por miedo del desseo, que me tienen amenazado, muchas vezes non vos veo.

El cruel, falso' nvidioso, por envidia vos mirava, dixo que quién me mandaba mirar gesto tan fermosso; por tanto, mi bien, non oso mirarvos como solía. penssat que me mataría car assí lo tiene jurado. ${ }^{16}$

Is Spearing assumes an inter-relation of the two senses (1993, pp. I-2, I4O-55) as part of voyeurism. Also see Burke (2000, pp. 80-8I), and Carruthers (1990).

${ }^{16}$ Palacio ms offers no interrogation marks but does accent the interrogative pronoun; Casas Rigall (1995, p. 135) closes the question at the end of 1.2 and corrects to "tienen amenazando" against the manuscript reading, to "amenazado". This reading is semantically coherent and rhyme may have been with 11. I and I3. Metric considerations are not conclusive. 
The lyric persona dare not gaze upon the beloved, as he has been wont to do, for fear that his expression reveals his desire. He exercises his gazing in the public arena where he is as susceptible to observation as the beloved. A cruel and envious on-looker observed the lover looking at the beloved and threatened to kill him. The generalized visual sphere is depicted as a public space in which the very act of looking itself is subject to perception by others and can excite their visual interest (11. 6-7); looking is an act governed by the Lacanian symbolic order; that is, the subject's acceptance of his/her entry into language, power structures and relation with the laws that govern behaviour in all areas.

In “¿Qué será de mí, cuytado?” Torres orchestrates the exposure of the lyric subject in the visual sphere as the subject of a gaze in which the relationship with the on-looker is asymmetrical since that on-looker poses the threat of death. The asymmetricality lies in the fact that, first, the lover looked without being aware of being seen and, second, he recognised that he has access only to a partial view of the totality of the generalized visual sphere: "the point from which I may be gazed at is neither the point at which I look nor the point from which I see" (Kay, 200I, p. 269, paraphrasing Lacan, 1973, p. I62; see Gaunt, 2006, p. 83 for discussion of original). His public looking is an exposure of what is not licit, a transgression of the symbolic order, and as such it produces a traumatic threat prohibiting his capacity for action, particularly to exercise scopophilia, or concupiscentia oculorum, the focusing of desire in the act of looking.

The on-looker's verbal articulation of the threat suggests that he enjoys a position of power over both the lover and the beloved since he can police visual access to the latter and both threaten and aggressively question the lyric persona. In his discussion of Geoffrey Chaucer's The Knight's Tale, A. C. Spearing notes that Duke Theseus's "gaze marks his public dominion" (1993, p. 22) and encompasses the subjects whom he may command. If the visual sphere is a generalized sphere in which the bearers of power may look publicly then the psychic asymmetricality of viewing becomes an inequality of power. In a Lacanian reading, the exposure of the lover's awareness of the asymmetricality of the gaze is an uncanny moment of traumatic psychic disturbance. ${ }^{\mathrm{I}}$ The subject cannot know if he is seen from the place where he looks for recognition (the Lady), cannot receive the Lacanian "don suprême" of the Lady's recognition since his own looking is now barred (see Lacan, 1993, p. I52). However, since the subject must seek a guarantee

${ }^{17}$ On scopophilia see Spearing (1993, pp. 6-10).

${ }^{18}$ For discussion see Gaunt (200I \& 2004), and Kay (200I, esp. pp. 269-270). 
of his own integrity as a subject he must continue to seek it somehow, anyhow from the Other.

Further, the lyric persona responds to the threat by attributing negative traits (cruelty, jealousy) to the on-looker, which are traditionally associated with a husband or guardian: those legally entitled to have control over the lady and protectors of such symbolic capital as is vested in her person (family honour, access to heredity, and so on). The asymmetrical structure of the gaze is such that to look openly is to invite physical destruction (and not merely psychic disintegration in the experience of amor hereos). The on-looker's licit scopic field encompasses not only the lyric persona's looking but also the beloved (1. 7). The power to grant recognition resides in the law but the subject seeks it not there but in the oblique approach to the elusive Other.

Access to the generalized visual sphere is structured through a hierarchical scheme in which entitlement to exercise the scopic drive fully is restricted. Depending on how the reader or audience interprets the scenario, the on-looker exercises a male gaze (the beloved is his possession to which he controls access, only he may assess her worth) or as a dominant rival or obstacle (social superior, father, husband) who has the power to control the visual sphere regardless of his relation to the beloved and who is a conduit of the laws-of-the-Father as they reside in the symbolic order. The socio-political constraints of feudalism are registered in the lyric commonplaces deployed in either case causing a dissonance. Amatory discourse in male-voice court poetry is a play, in every sense, for status; a step out of the manifest content of the dynamic of the heterosexual couple and into the social and political horizons of the homosocial sphere of power; the symbolic register, the place of language and the Law-ofthe-Father. ${ }^{\text {19 }}$

The lover, in contrast, is forced to suppress his looking ("non miro [...] non vos veo [...] no oso / mirarvos", ll. 2, 5, IO-II) at the desired object and this gives rise to the lyric utterance, which serves as an explanation to the beloved as (imagined) sole recipient of the song, who is paradoxically also figured as the object of the (audience's) look within the body of the song. His repression of his own looking is a barring of the male gaze by an absolute Other, a force beyond desire, and his song is a move towards Lacanian jouissance, a transgressive overflowing of pleasure/pain, a trembling before the trauma occasioned by the possibility that

19 For the founding study on and definition of homosociality see Sedgwick (1985), and on the feudal metaphor in troubadour lyric see, for instance, Gaunt (200I, pp. 478-482). On court poetry as play see, for example, Burrus (1998). 
the other may lack also, may not have the power to recognize the imagined integrity of the subject. Yet the subject resists the law-of-the-Father and his barred access to the other: the beloved is present as what was once seen by the lyric subject but is now veiled from his sight even if still viewed by the on-looker. As he puts her into words, she is present in his mind and is conjured into the generalized visual sphere as (un)seen (or absent?) object and so her power as a fantasy Other that guarantees the subject's integrity is held up.

Torres's play with tension in lyric utterance between the private and the public spheres, and the capacity of lyric to make present —or visible to the mind's eye- what is absent, or barred from sight, is clear also in his interlinking of the themes of knowledge, sight and absence. "Sepas tú, senyora mía" (IDo404, SA724; Palacio, p. 24) is typical of how he does this. Its surface simplicity belies its conceptual complexity, and I cite it here in full:

Sepas tú, senyora mía,

a doquiera que seré,

tu gaya filusumía

ante mis oxos veré.

Pensando en tu fermosura

siento infinido plazer;

tanbién rezibo tristura

por absente de ti ser;

mas toda mi alegría

sé bien recobraré,

quando tu filusumía

antes mis oxos veré.

It may be one of the number of Palacio compositions, such as García de Pedraza's "Sepan cuantos esta carta" (ID24I3, SA7-22; Palacio, pp. 20-23), whose opening lines echo the notarial epistolary formulae of public address as opposed to formulae of private correspondence. If so, the lyric subject directly addresses (or imagines himself addressing) the "Senyora" from a position of absence through the medium of the written word. I do not insist on this reading since the song may equally be interpreted as a(n imagined) direct verbal address to the Lady. None the less, the presence of analogous allusions to such formulae in other Torres compositions makes my proposed reading at least feasible.

His "Quien lo lee bien s'avisse / et sepa tanto tú de mí" (ID2589, SA7-208; Palacio, pp. 198-199) more directly emphasizes the written word as a mediator 
between the lyric persona and the beloved than "Sepas tú". ${ }^{20}$ Although this song opens with a phrase that suggests his words are for public consumption, the introduction of the second person is reprised after the lyric persona avows his love in the opening refrain and addresses the love object directly as implied sole recipient, "Pues tú que lees mi letra, / pienssa qué deve sentir / quien de tu vista partir" (11. 5-7; my emphasis). The narrator imagines his billet-doux, perhaps his handwritten words, read by - maybe also held in the hands of - his beloved during a separation. ${ }^{2 \mathrm{I}}$ Absence from the gaze, vista, of the beloved pierces his heart causing grief. Here Torres's wittily inverts the received heart-and-eye topos: it is the absence of the lady's gaze that causes pain and not the piercing gaze itself. ${ }^{22}$

Further, Torres is capitalizing on the fact that court lyric potentially exists as oral and written genres for both public and private consumption. Although his lyric purports to function as private communication to an implied addressee as song or written text, its genre status as (potential) performance text suggests that a wider audience may actually receive it aurally in keeping with the formula alluded to in the opening and its compilation in a cancionero records its wider circulation. As such, the wider reading or listening audience become spectators (auditors) of the address of the lyric persona to the beloved whilst not (necessarily) being privy to their identities. In the light of my reading of "Quien lo lee", it seems at least feasible that Torres's evocation of the notarial formula in "Sepas tú" fetishizes the letter, as message text and material object, in the sense that it is an object that serves as focal point for lyric subject's desire.

In this analysis, the letter stands as a physical screen or veil between the lover and unseen gaze of the beloved. It is that which is permitted to be object of the look, to become intromitted, impressed on the faculties and incorporated. But it is also that which, by anamorphosis, raises the beloved to the status of the Lacanian big Other; a terrifying and literally mortifying Other erected to shore up the subject's identity. Consequently, the lyric persona per se is not exposed to

${ }^{20}$ I find the syntax of this song obscure in places. Dutton reads "bien savisse" (1. I, with Krogstad, I990-9I: IV, p. I34b; see Palacio on-line, fol. 9Ir), having previously had the unsupported supiese (1982). I am inclined to accept Álvarez Pellitero's reading, interpreted loosely as "Reader, be well advised and know this much about me".

${ }^{21}$ In the period I420-I440, CORDE records both senses in use.

${ }^{22}$ Spearing (1992, pp. 9-IO, 22) coins the term to refer to the lover's feeling himself wounded to the core and incited to love by the lady's eyes or her look. See Torres's "Cuytado, qüando cuydo" (ID2717: SA7-364) for a more conventional evocation of it. On the topic, see Spearing (1993, pp. 8-IO, 39-4I, 76-77, I64-I65, 238-239, and 242-244). 
the gaze of the Other (and the threat that lies beyond it), not forced to deal with the trauma of the castration complex nor yet prohibited the fantasy of being constituted as "whole, unproblematic" (Gaunt, 2004, p. 82). ${ }^{23}$ The depiction of her intromission of his words stands as a fantasy of recognition of the integrity of the subject by the Other.

Alternatively (or also), it may stand as a synecdoche for the poet's penetration of the beloved ('s soul). In such a reading, the song presents a daring and provocative manoeuvre that cancels the "paradoxe amoureuse" (Spitzer, 1944, pp. I-2) - "a highly refined way for making up for the absence of the sexual relationship, by feigning that we are the ones who erect an obstacle thereto" (Holsinger, 2005, p. 89) by ascribing responsibility for the wound of love to the beloved - to figure the beloved as agent in a sexual encounter; she reads, she intromits. Medieval sight was a somatic, even potentially sexualized, operation, as Folger observes (2009, p. 52). In a Lacanian reading, it could be argued that the desire for such psychic merging contains a residual trace of longing for a pre-symbolic union with the maternal prior to entry into language and recognition of mother's (our own) lack. Consequently, the beloved is positioned in the place of the big Other; "cet Autre absolu, cet inconscient fermé, cette femme impenetrable, ou bien derrière celle-ci, la figure de la mort" (Lacan, 1994, p. 43I); "that absolute Other, the inaccessible unconscious, an inscrutable woman, or even, behind her, the figure of death" (Gaunt, 2004, p. 82). ${ }^{24}$ In a utopian Jamesonian analysis, the yearning for merging might be seen as a desire to participate in social collective rather than a reach for the pre-symbolic. At the very least the letter figures the indirect approach to power.

The social or performative nature of Torres's poetry is evident elsewhere. For example, his poetic persona also engages with his (implied) audience in the decir, "Grand'enoxo en yo bevir" (ID2486, SA7-95; Palacio, pp. 9I-95). The decir turns around the very core of desire: not the Lady as object, but the Lady as substitute for that which resists signification. Through the first six stanzas, the decir is riven with the lover's desire to speak out and publicly articulate what must be silenced

${ }^{23}$ Anamorphosis is defined in more detail below; also see Haywood (2008, p. 133) and Gerli (20II, pp. 33-35 and 94-97).

${ }^{24}$ I refer readers to Gaunt (2004, p. 82), who gives a particularly accessible account of the Lacanian gaze, as interpreted by Slavoj Žižek, and its prefiguration in Occitan troubadour lyric; the importance of which for the modern laws of desire Lacan himself underscored insistently (1994, p. 43I). 
and what, ultimately, cannot be — but is, despite the outward display of not speaking out- articulated.

Unlike "Sepas tú" and "Quien lo lee bien s'avisse", the audience of "Grand'enoxo" shifts throughout the poem. As the decir opens the narrator adopts a personal, meditative tone, addressing an unidentified reader, "Yo suplico a quien leyere / las simples coplas presentes" (11. I7-I8; my emphasis), before evoking a modesty topos in which he attributes his fallibility to his psychic disarray ("mi flaco sentimiento" and "mi travieso pensamiento", 11. 2I and 24) and beseeches his reader (1. 40) to overlook his errors. The poetic persona suffers under the burden of secrecy until the tension of the repressed drive to put desire and the desired object into language — "esto que fablo contigo" (1. 40) — causes a public outpouring, "pues, amadores, guardat" (1.67), that defines the narrator as an unrequited lover and describes the surpassing excellence of his love object.

Already ambivalent about the oral or written status of the utterance, the poetic persona introduces the avowal with a phrase that marks the transition from meditation to statement, "por esta razón escrivo / lo que se querrá seguir" (ll. 47-48). He then adapts the epistolary formula to make a public declaration of his status as lover, "Sepa Dios e todo el mundo / que yo só enamorado" (1. 50-5I). The declaration reverses a reflection from his opening meditation that, "Yo sufro lo que Dios sabe / e omne del mundo no" (1l. 9-10), which can be interpreted, first, as an assertion of secrecy with God as all-knowing panopticon ("God knows what I suffer, no human being does"), and, second, as describing the depth of his pain ("God understands what I suffer, no human being can"). Through the ambivalence of this declaration, the related topics of secrecy and what can be known are introduced.

Torres plays craftily and wittily with the control of access to knowledge: his avowal, for example, is centred on self and, in actuality, reveals nothing about the beloved other than her failure to reciprocate his feeling. The decir stages a public show-and-tell, in which the act of writing stands in for the existence of a trustworthy interlocutor, yet reveals nothing that cannot be deduced from the commonplaces in the opening words. As A.C. Spearing observes secret looking is associated with power since the secret is a refuge "against the determining claims of the public sphere" (1993, p. 22) thus to expose oneself as a poet and a lover is to stake a public claim to a particular type of identity and status, and to do so whilst successfully concealing the identity of the lady is to display the courtly virtue of discretion and exercise power in the public arena. Again, courtly discourse is a play for status: a bid for recognition in the symbolic order and an articulation of the social and political horizons available to the subject within the laws of desire. 
Consequently, this lyric is a poetic tour de force of diplomacy in which the public and private arenas collapse into and onto one another: private meditation (if it was ever such) becomes public declaration.

In the last stanza, the poetic persona narrows his focus to address lovers, whom he challenges to contradict his assertions about his beloved. His implied audience ranged through personal meditation, an imagined interlocutor, God and the whole world, and narrows now specifically to lovers; that is, to those involved in the same dangerous game of making themselves seen and heard at court. Finally, Torres uses polyptoton in the fin to recall the epistolary formula once again and to emphasize knowledge: ${ }^{25}$

Sepa quien saber quisiere

e diga'n toda parte

que soy amador sin arte

e seré mientre viviere. (11. 73-76; my emphasis) ${ }^{26}$

Although he declares himself to be a simple lover, the intellectual complexity (and the game of show-and-tell) of the decir suggests that he is an ingenious poet (poeta con arte), conscious of the literary and rhetorical strategies deployed. The self-conscious and reflective qualities go beyond a cursory modesty topos and reverberate with some of the poetic compositions of Don Ińigo López de Mendoza, later Marqués de Santillana, which appear in Palacio.

Torres's challenge to lovers has not gone unmet. Amongst the decir's wider audience was Alfonso de Barrientos, who responds to it in his, "Quando pienso en la canción" (ID2567, SA7-I8I; Palacio, p. I84) by revealing a secret of his own about love. ${ }^{27}$ Barrientos's emphasis on secrecy supports my assertion that this is one of the central themes of the decir. Although secret, the amatory affair in each case is staged publicly. The competition is not between lovers for a particular lady but between poets in a display of personal, but politically expedient, qualities. Speaking about love should be to speak discretely in the public sphere, to reach for the supreme gift of being recognised as one would wish to be seen and to be seen being seen, to have one's identity guaranteed.

${ }^{25}$ Polypototon and other figures of annominatio are frequent in Torres's work.

${ }^{26}$ The manuscript gives a hypermetric "quien", confirmed by Barrientos's citation of the line.

${ }^{27}$ I shall return to citation practices in Palacio from socio-political and psychoanalytic perspectives in a future study. 
Central to "Sepas tú" is the creation of imagined distance and an asymmetricality between the lover and beloved. The distance is physical, mental and in relation to access to knowledge; a theme also found in "Grand'enoxo". The "Senyora" of "Sepas tú" cannot be absent from the lover since her image ("tu gaya filusumía", 1. 3) is always present before his eyes wherever he may be. What may now seem like cliché was anchored in the contemporary understanding of mind and memory. That is to say, the lyric persona's visual perception, a mental image, of her face has been impressed directly into memory, leaving a trace much like a signet ring in wax. ${ }^{28}$ Thus the lyric asserts that through cognition the lover can overcome physical distance and have her always with him. In contradistinction, the lover can be absent from his beloved ("por absente de ti ser", 1. 8). Note that the merging of lover and "Senyora" here is figured quite differently than in "Grand enoxo", and this, I believe, favours a reading grounded in contemporary scholastic and philosophical theory.

Contemplation of the beloved's beauty in the lover's absence causes him an oscillation between pleasure and pain, an approach to that jouissance which lies beyond the symbolic order in the fantasy of a situation in which the subject reaches for that Other who may bestow the gift of recognition whilst it can be neither given nor received. The fantasy perhaps even raises the spectre of the trauma that the beloved erected as Other "does not have the power that the subject imagines it has to confer [...], the trauma that the Other may be lacking" (Gaunt, 200I, p. 49I) since it dramatizes the absence of the Other experientially whilst guaranteeing her existence in memory. However, Torres moves away from traditional configurations of the commonplace poetic antithesis (presence/absence: pleasure/ pain) to impose linear temporality: there can be an end to suffering and a return of joy. ${ }^{29}$ The "Senyora"s image excites infinite pleasure, his absence from her causes sadness but he knows that his happiness will be fully recovered when he sees her before his eyes. The beloved is unknowable and unknowing and is yet capable of being possessed as a contingent source of pleasure / pain in her absence, saturating the lover's experience only in her presence. The lover permits the fantasy of trauma before banishing it in the face of the reach for the Other, shoring his identity up in the fantasy of a direct approach to the beloved.

${ }^{28}$ On the function of medieval memory see Carruthers (1990 and 1998), Crombie (1990), Spearing (1993), Klassen (1995), and Burke (2000). Readers of Carruthers (I990, pp. 24-5) will recall the signet ring image, although ancient, is present in Plato and Aristotle (pp. 17, 29I). Álvarez Pellitero describes filusumía as "un vulgarismo muy poco utilizado por fisonomía" (I990, p. 24 n), occurring elsewhere in SA7.

${ }^{29}$ This is Pierre Bec's phrase; see the discussion in Kay (200I, pp. 3-5). 
The conceit at the heart of the song is that the contemplation of the beloved's mental image is accompanied by cognisance of the physical distance separating them, and so memory and imagination can never be the full source of pleasure ("toda mi alegría", 1. 9) that actually seeing her is. The physical separation between lover and beloved is likewise emphasized by the song-as-letter of "Quien lo lee", which is figured as a sense-image: both as a physical object held by the beloved and as an object and a set of concepts that are intromitted through her eyes to penetrate her heart, figurative seat of emotion, "mi letra [...] el coraçón le penetra". Yet the manifest content of "Quien lo lee" depicts the pierced heart of the absent lover and is an appeal for affective response, a plea for recognition.

As suggested above, the opening verb ("Sepas") alludes through polyptoton with the notarial formula, "Sepan cuantos esto leyeren...", emphasizing the transmission of previously unknown information to the recipient. The formula is more appropriately used for a public document than in private correspondence and usually addresses an implied audience of unknown recipients; the song is directed to an (unnamed) implied individual. Significantly, in each case, the phrase suggests that the recipient is unfamiliar with the content of the message and that the emitter controls the flow (is the source) of knowledge. Thus, on receiving the song, "Sepas", the "Senyora" learns that the lover has incorporated her face, "tu gaya filusumía", into his memory store. Although part of a formulaic address to the beloved, the possessive adjective, "mía", comes to suggest his possession of her through the imprinting of her image into his memory store, in this case her face stands by synecdochal syllepsis for the beloved herself, and the erotic implication maybe that the lyric persona and the "Senyora" will enjoy sexual possession of one another when they are reunited. The supplicant scripts the interaction and so represents the "Senyora"'s gift of recognition as she incorporates his words.

"Pensamiento, soledat" and "Departa en toda partida" (ID2450 and ID245I, SA7-60 \& 6I, respectively) may form part of a thematically-linked series on folios $2 \mathrm{I}^{\mathrm{r}}-22^{\mathrm{r}}$, turning on knowledge and the separation of self from other. The series —including "Si el pensar" and "Esperando desespero" (ID 2452 and ID2453, SA7-62 \& 63, respectively; Palacio, pp. 45-48) — appears at the end of a group of fourteen Torres compositions running from fol. $188^{\mathrm{V}}$. In a courtly reading of "Pensamiento, soledat" the lover, represented metonymically by his heart, is troubled by thoughts, solitude and desire as he awaits compassion from a lady who is seen today to be acting cruelly; if Love were to act in faith (lit. in truth), the lover's loyalty would be rewarded willingly. Loyalty is reprised as a light motif in "Si el pensar" (1. 9), although merely in the protestation of steadfast service, and is lexicalized in "Esperando desespero" (1. 9). On the erotic level, the lady is represented 
as dissembling: were she (represented by Love) to act truthfully she would recognize his loyalty and willingly consummate their relationship. Torres heightens the dissonance between the courtly and erotic levels through use of euphemistic religious and feudal lexicon: piedat, verdat, consolaçión and lealtat.

The linked semantic fields of thought and knowledge run through the group. "Departa" deals with the lover's loss of self-knowledge through separation from the beloved, playing throughout on different senses and grammatical forms of partir (see discussion below). "Esperando desespero" similarly revolves around the lover's unflinching loyalty, now in the face of an unwelcome separation from the beloved, which drives him to despair, "m’a traýdo / este mal de que yo muero" (1l. 5-6). In "Si el pensar", the lover will be driven to despair ("por perdido [...] soy traýdo", 1l. 4 \& 7) should the beloved turn against him ("contra mí es falleçído", 1. 3). The past participle of "traýdo" at rhyme position in the pie quebrado of the opening of "Esperando desespero" echoes its use as adjective at rhyme position in the pie quebrado of the vuelta in the previous song, "Si el pensar", reinforcing the link between unshakable loyalty and the lover's altered psychic state in each composition. Likewise partido, whose lexeme partir is the base of "Departa", appears in "Si el pensar" and "Esperando desespero" in different senses: not being prevented from praising the beloved in song and a separation, respectively. To Mosquera Novoa's observation that there is metric and thematic continuity between some of Torres's Palacio compositions - specifically, heterometric stanzas in ID2449, 2450, 2452 and 2453, psychic turmoil in ID2449 and 2450 and slightly longer length in ID2452 and 2453 (269-270) — can be added further shared thematic concerns and rhetorical techniques, such as syllespsis, polyptoton, and polysemy, thus the group under discussion can be said to form a series.

The song, "Si mis tristes oxos veen" (ID259I, SA7-210; Palacio, p. 199), deals more explicitly with the capacity of sight to possess. The lyric persona entreats Love to permit him, again by synecdochal syllepsis, not to desire what he will never see, since for his eyes to see is to possess:

que si mis oxos posseen

lo que en'ver siempre poss[e]an

plégate que no desseen

lo que nunca jamás vean. (11. 9-12)

30 The typographical convention of Palacio is to use italic font for the vuelta. Palacio (1993, p. 199) and the manuscript (fol. 9Iv) read "possan" (1. Io) but the metre dictates the need of an additional syllable, supported by the rhyme scheme, which demands -ean. 
The conceit underlying the song depends upon the reader or audience's knowledge that the process of seeing involves a possession, which on the manifest courtly level is simply the intromission of the sense-image of the object seen. The link is made clearer through the vocabulary employed in the comparatio in the stanza. The person who wishes for (dessea) good weather takes pleasure (góçasse) when it is seen. The comparatio clearly functions on a literal level; however, when the language is transferred to the sphere of desire through the working out of the points of comparison, it operates latently on an erotic level, as suggested by the Macpherson-Tillier mode of triple-entendre in relation to other cancionero poetry:

The approach to any given poem could be tripartite, allowing for the presence of courtly, erotic and religious elements [... in which] one might expect the presiding interpretation to be courtly, with religious or erotic connotations making a subsidiary, or less overt contribution. (Tillier, 1985, p. 65$)^{31}$

In this reading, the lover pleads that Love grant him sight of what can be physically possessed (referred to metonymically by reference to his eyes) since sight is a physical possession of the object that gives sexual pleasure (gozo).

Returning to the song "Sepas tú", Torres plays on the verb saber through polyptoton in the line introducing the vuelta to link knowledge, possession and pleasure: "sé bien que recobraré [toda mi alegría]". The lover is certain in his knowledge that in the future he will see his beloved before his eyes, and the recovery will be a full source of pleasure. Unlike the "Senyora", he possesses knowledge. The assurance conveyed by the mood and adverbial qualification stand in contrast to the opening verb, creating a series of dichotomies around the subject and the other. Torres contrasts the lover's knowledge with the "Senyora"s lack of knowledge. The lyric persona reveals to the "Senyora" that he possesses her (mental) image. There is no mention of whether she reciprocates his feeling, similarly has his image impressed upon her memory, was even aware of his absence or knows that she is the implied addressee. The "Senyora" is static, resists symbolization, yet is susceptible to incorporation but available in the lyric frame only indirectly (through memory). Torres's deviates from the received motif of two lovers parted, rather the lover is absent from her presence, and suffers a lack that can only be fulfilled in her presence; something that the lover insists will be experienced. The focus on his absence from her — rather than a simple separation

${ }^{31}$ Also see Macpherson (1985), and Whinnom (I98I). 
or parting — is a distinctive feature of "Sepas tư", which merits further examination, as I hope a brief digression into Torres's other compositions on parting will show.

Most like "Sepas tú", in my view, is the song "Si vos plaçe que mantenga" (ID2473, SA7-83 and 218; Palacio, pp. 67 and 20I), which also relies on a scientific understanding of sight. Like "Sepas tư" it directly addresses the beloved but uses the honorific vos form. It is structured around the antithesis of presence / absence; however, its articulation of the antithesis is different, with the accent on presence. The fantasy of proximity, expressed through litotes ("de vos no mucho apartado", 1. 6), causes the absence of sadness ("por partir de mi cuytado", 1. 7) by permitting the lover to gaze upon the beloved. If she reassures him of desire, "lo otro vaya et venga". It is precisely in this search for desire, for the desire of the mythical complete Other, that the subject is constituted, is reassured in his integrity (Lacan, 2004, p. 235). As in "Sepas tư" the lover alludes explicitly to cognition, "pues mi pensar / bien alongado lo veo" (ll. 9-IO), perhaps recognising the unlikelihood of achieving his desire, also expressed in terms of absence and distancing. However, pensar here may also stand by syllepsis for the beloved so this phrase could be read as, "since I recognise my beloved is far away". The lyric persona's utterance vacillates in the moments of projecting the need for recognition onto an other, the fantasy of receiving such recognition and the trauma of its impossibility.

"Departa en toda partida" (ID245I) is a tour de force of figures of annominatio on partir, "to divide; separate by force; leave; distribute into parts, share", and its derivatio, departir, "to discuss, deal with; divide into parts", with epistrophe throughout, and the anaphoric derivationes "Departa" and "Pártome" in the opening lines of the refrain and mudanza, respectively. ${ }^{32}$ Its complexity makes it worth quoting at length prior to discussion:

Departa en toda partida quien quisiere departir de la mi triste partida, c'ora me conviene partir.

Pártome donde se parte mi coraçón tan partido,

${ }^{32}$ I draw my English definition from a reading of CORDE entries, the Diccionario de la Real Academia Española, and Corominas (1991). 
que non sabe de si parte

en graçia ni buen partido;

mi voluntad no es partida

aunque quïero partir,

pues la tengo ya partida

con quien la puede partir. (my emphasis)

Torres's composition can be read as showing a keen awareness of the use of departir and partida as terms employed in book organization and logic; for example, in chapter summaries and epigraphs and in the divisions of concepts in explicit statements of material to be treated. ${ }^{33}$ The lyric persona's departure may be dealt with in each of its divisions (parts) by anyone who wishes to do so. Through the introduction of paronomasia on partir, the lyric persona states that it now falls to him to take his leave, to divide his departure, partida, into parts for commentary (as in the division of a sermon's thema or the parts of a logical argument) and to subject the partida to derivatio ("me conviene partir", 1. 4).

The figure of paronomasia then takes equal force with annominatio to offer a series of overlaid readings. The lyric persona leaves the place where his greatly divided heart is sundered. It knows not whether he leaves in grace or buen partido, through paronomasia, a good (or welcome? or advantageous?) departure, a witty move or a successful annominatio ("buen partido"). ${ }^{34}$ The complex 1. 9 (emphasized above) may be construed as meaning that: (i) his decision is made; (ii) his will accords with his other faculties; (iii) it is not sundered into parts; and, (iv) he has not lost his mind. For each of these readings, I am taking voluntad (lit. the faculty of will) as a metonymy for the lover's mind. In readings (ii) and (iii) voluntad may also operate through metonymic syllepsis to refer to the lover himself. Despite the statement in 1. 9, he wishes to leave. Although this is so, his will is already sundered since it is shared with the beloved who is able to take it (or is entitled to share it?). The lexical content and rhetorical ingenuity of the song seem to me to be more prominent than its message content such that it is as much about the rhetorical operations of annominatio and paronomasia as about parting. In other words, the song enacts at a rhetorical level the physical separation and psychic shattering as they are experienced by the lover in absence. To my mind, "Departa en toda partida" is an extremely technically accomplished

${ }^{33}$ See "departe en" in CORDE for the acceptation of chapter summaries and of the division of parts into a logical sequence for discussion.

${ }^{34}$ I have been unable to find the last two meanings given here unambiguously attested in CORDE but the context suggests their plausibility. Ll. 7-8 seem obscure. 
composition, in which Torres reveals himself to be keenly aware of the artifice of courtly poetry.

In the final two compositions to be discussed in relation to "Sepas tú", the lover addresses the beloved directly. In "Esperando desespero" (ID2453, SA7-63; Palacio, pp. 47-48), the poetic persona protests his loyalty whilst complaining about the parting, not wished by the beloved: "veo que non dexo / a quien me quiere dexar" (11. 19-20). ${ }^{35}$ Unusually, the lover himself has chosen to leave, and is cause of the consequent emotional suffering, "por mí fue escogido el partido" (11. I4-I5). Despite his loyalty, the lover has been caught unaware by his situation, "quando cuydé ser despierto / falléme muy adormido" (ll. 9-Io), consequently he welcomes the ensuing suffering since he is responsible for the departure that alienates him from himself, and separates the two geographically, "el partido / de que me fallo'strangero" (11. I5-16).

In "Si por mal en que me viesse" (ID2447, SA7-57; Palacio, p. 44) the separation has already taken place. Here again the lover appears to be the agent of the separation: "Depués que partí de ti [...]" (1. 4). The lyric persona (humorously) curses himself should it ever occurred to him to forget the beloved no matter how dire his situation. The notion of "finding oneself" in the sense of discovering or realising oneself to be in a particular situation is lexicalized, as extensively elsewhere, through the reflexive verb verse, here in the opening refrain, with a variation in the vuelta: "Si por mal [por cuyta] en que me viesse" (1l. I and 8, variation in square brackets). The repetition with variation of these words foregrounds a key ironic ambiguity in the song. It can be interpreted as meaning that, although the lady is the root of his thoughts, it is not the separation or her central role in his thought processes per se that has caused the lover's suffering but the disadvantageous situation and suffering experienced as mal, cuyta and tormentos (11. I, 6, 8). In other words, the song may point beyond itself to an extradiegetic context, a situation external to the lyric world, which is the source of the lover's literal suffering. Alternatively, dwelling on the beloved, and his absence from her, could be read as the cause of his suffering. I am inclined to view this as a deliberate ambiguity on the basis of Torres's multiplication of layers of meaning elsewhere.

Further, the second reading is supported by the manuscript context. In "En me sentir amador" (ID2448, SA7-58; Palacio, pp. 44-45), which follows "Si por mal" in Palacio, the lyric persona discusses the paradoxe amoureuse by which the

${ }^{35}$ Whilst 1. 4, "Leal es vuestr'apellido", metaphorically suggests the lady demands loyalty and/or is loyal herself (see ll. 19-20), it may also be read literally as an encoding of the addressee's name. This would open the composition to an erotic reading. 
beloved is a good, "mi bien" (1. 7), worthy of the lover's suffering, "cuytas, trabaxos et males" (1. 8): here his suffering arises directly from the amatory situation. However, in this case, if the beloved were to accept the lyric persona's profession of amatory servitude, "me creyese / que yo soy tu servidor" (1l. 9-Io), his belaboured heart — himself by metonymy — would lose its fear of being forgotten. It is possible that Torres composed (or compiled?) these two lyrics as a pair that work out the motifs of the lover's suffering (thematicized lexically through polyptoton and litotes sentir / non siento in "En me sentir") in relation to forgetting: the lover who forgets to suffer for the beloved versus the lover whose suffering results from being forgotten. A variant of this structure is found in "Si el pensar", from the same group of Torres compositions. In this song, without forgetting and with intense feeling, the lyric persona serves the beloved and utters the vuelta, "que, sin errar, / soy traýdo".

As in "Si por mal" and "En me sentir", the beloved of "Sepas tú" is the implied recipient. In "Si por mal" and "Sepas tú", she is also the focus of thought whereas in "En me sentir", the lyric persona is himself concerned with being (or becoming) the object of thought. Taken together the three lyrics expose amatory experience as deliberately engaged memory work: loving is not forgetting; not loving is forgetting. ${ }^{37}$ To love is to possess the love object; that is to say, to intermit her sense-image or species and to maintain cognitive focus on it. The scopic drive is fulfilled by contemplation of the memory image but full saturation may only be experienced in meeting, in a courtly reading, and (mutual) physical possession in an erotic one. In other words, the subject's identity can finally only be guaranteed by the supreme gift of the Other's recognition, achievable only as projected fantasy within the lyric frame.

By my reading, informed by the compositions discussed here, "Sepas tú" brings together the spectre of the "Senyora"'s gaze, the poem of lovers' parting and the evocation of cognitive processes, particularly reading and intromission. I wish now to turn to consider Torres's treatment of the "Senyora"s exercise of sight in more detail, and to consider once again the association between the scopic drive, sexual possession and pleasure. Sight is an organizing trope in the decir, "Cuytado, qüando cuydo" (ID2717, SA7-364; Palacio, pp. 382-83), which begins as a meditation, addressed to the "Senyora", on the lover's suffering: the

${ }^{36}$ Álvarez Pellitero (Palacio, p. 47, n. 7) considers traýdo to be used in its antiquated sense of betrayed. Although contextually apt, I have found no other acceptations of this usage in the period I4IO-I44O in CORDE.

${ }^{37}$ On willed recollection see Gatland (2010), and Carruthers (1990, pp. 59-60, and 7I). 
only good he receives is from serving her. Without any cause, his sole error has been to meet the "Senyora", "vos ove conoçido" (1. 4), with the result that her thieving eyes and noble bearing have stolen his mind (lit. sense) and heart: ${ }^{38}$

vuestros oxos robadores

me robaron el sentido [...]

e deseo afincado

de vuestro gentil aseo,

el qual este, según veo,

á mi corazón robado. (11. 7-8, I3-16)

The first-person singular veo indicates the link between cognition and visual perception: to see is to process intellectually, to realise. Although a rather mundane expression, it is worth observing that Torres's song, "Non me basta discreción" clearly uses veo in this metaphoric sense:

Yo veo tan inposible

aver fin mi grant desseo

por lo qual es muy terrible

mi locura, según veo (1l. 5-8).

In "Cuytado, qüando cuydo", it is by seeing the "Senyora"s noble bearing that his heart is lost. The logical corollary of this is that it is by looking at her eyes his sense is lost. In rhetorical terms, inanimate physical features (eyes, bearing; heart, senses) are personified and through metonymic syllepsis represent her beauty and his love; however, these traits also stand for the individuals themselves, beloved and lover, through synecdoche. ${ }^{39}$

In the compositions discussed above the potency of the female gaze (in the sense of the uncanny and mortifying power of the Other's gaze) is muted by being directed not at the lover himself but at material objects that convey textualized traces of his cognition. The lover can be figured as intromitted but only through symbols (his word, his script), which stand in for him and which are wholly his whilst also being wholly of the symbolic order. The indirectness of the sight line resonates strongly with the Lacanian figure of anamorphosis, al-

${ }^{38}$ Rodado Ruiz (2000, pp. 64-67) discusses motifs associated with eyes.

${ }^{39}$ For an excellent discussion of these operations in relation to cancionero poetry, including Torres's “¿Qué sera de mí, cuytado?” (ID2597; SA7-217, discussed above) see Casas Rigall (I995, pp. I33-I36). 
luded to above, whereby the object cannot be seen in the same plane (or visual register) as other items in the ground — or generalized visual sphere — but rather only apprehended indirectly or from a vantage point at which the generalized visual sphere is distorted. The direct contemplation of the beloved is figured only indirectly through memory work on her intromitted image: she is subject to cognition in absence and direct apprehension of her provokes trauma and its concomitant suspension of cognition. Courtly anamorphosis in contrast is a source of pain / pleasure, an attempt to approach that which can be intuited beyond the symbolic order but which resides in a different register. The beloved becomes the Lacanian Thing, that unfathomable barrier to jouissance whose mere existence points to its presence beyond the symbolic.

If the visual sphere and memory are the ground against which amatory experience unfolds, then logically forgetting takes on a key role in the psychic structure of the relationship since to forget is to cease to function psychically (and somatically, since bodily suffering will end) as a lover. The logical corollary of this is that to be remembered (or not to be forgotten) is to be intromitted, possessed and to become object of the beloved's attention. In an erotic reading, what is at stake is the establishment of sexual union and the pleasure which flows from it.

In contrast, in "Cuytado, qüando cuydo", the mutual gaze may be a direct and reciprocal, if momentary, looking in which it is to be hypothesized that the pneuma sent out from eyes of each party and/or the species — simulacra or images - of the object carried back to the beholder subject meet and intermingle. The lover's cognition, sentido, is suspended when the species of the "Senyora" enter his mind. However, what he first registers are her eyes; thereafter, the object of his desire or scopic drive is her noble bearing. His looking performs a kind of fetishistic (non-Lacanian) gaze in which the look may only dwell on a part of woman. On meeting her (seeing) eye he encounters a suspension of self: infinite suffering and attenuated desire (lit. constant desire $)^{40}$. Her gaze, in turn, functions analogously to the Lacanian gaze, in which the subject experiences his exposure in the visual field as a traumatic destabilizing encounter with his own disunity seeking recognition and is confronted by lack. Sarah Kay (200I, pp. 269-27I) underscores

${ }^{40}$ In the period I400-I440, afincado most frequently collocates with verbs or nouns that refer to physical suffering or wounds: "afincado de la guerra", "muy afincado por ayunos", "en tan grand priesa, e tan afincado", and "muy afincado, e en peligro de muerte", inter alia (CORDE, 20Io). It may also have a temporal sense: "en este pensamjento afincado días \& noches"; or connote drawn out or persistent effort: "le rogava muy afincado", "pues quieres saberlo afincado", and "lo que diré afincado". Acceptations with reference to love are rare: "Amévos eu tan de afincado amor". 
the asymmetrical relationship that is established in this experience: "the point from which I may be gazed at is neither the point at which I look nor the point from which I see" (p. 269). The seen subject becomes object of another's view and the fantasy of the integrity of self (or Imago) collapses.

A strong taboo against looking, particularly a social inferior gazing openly upon someone - especially a woman - of higher social standing or a woman openly regarding or making eye contact with a man, shoots the moment in which the poetic persona sees what must not be seen (the female gaze? the mortifying gaze of the absolute Other?) through with an almost voyeuristic and certainly intense pleasure in the reciprocal gaze, the look into the uncanny with its concomitant suspension of cognition. ${ }^{41}$ This particular looking is not the male gaze, as classically theorized by John Berger (1973) and critiqued by feminist film studies specialists, as that looking that commodifies the woman by symbolic heterosexual possession. ${ }^{42}$ None the less, the poetic persona momentarily enjoys what is desired and prohibited: to be the object of the female gaze, to see oneself seen by her gaze and to see oneself being seen by her; that is, to figure the self as objectified and sexually appraised whilst also acting in the register of desire, seeing oneself as in the place of the desire of the Other. The erotic visual encounter cancels the taboo on the exchange of looks and levels the experiential categories of gender and social difference. In a utopian Jamesonian optic, the scopic drive moves the subject to a fantasy of participation in a collective in which sociallyconstructed hierarchical difference is irrelevant.

Further, at the level of erotic content, Torres may be drawing on the Biblical sense of conoçer (Macpherson, 1985, p. 54) to imply that the good he receives, and which is performed lyrically and in memory as a radical shattering of self, is sexual pleasure. Whether or not this is the case, the audience of the decir is drawn into a voyeuristic drama and figures in its our own imagination (for a contemporaneous audience, the read or auditory experience was reckoned to unfold pictorially in the mind) the interplay between them "en aquel día" (1. 2). External and internal space fold over one another as simulacra of an (imagined) encounter. Although the Lady is superficially structured as dominant, the legal language - it is her eyes that steal from him — encodes her actions as illicit thus reinforcing the dominance of gendered hierarchies in the symbolic order and the taboo against exercising the gaze in public space. Further, the poetic persona

${ }^{41}$ See Spearing (1993), discussed above, on control of the visual domain.

${ }^{42}$ Also discussed by Gerli (2OII, pp. III-II2). 
restructures the asymmetricality of the Lacanian gaze ("the gaze does not involve my looking but my being looked at", Kay, 2003: p. 164) to expose the beloved in the generalized visual sphere as an object to be seen, just as he is, in a levelling manoeuvre. Torres explores the asymmetricality of the gaze as a sensory-intellective activity that occurs in and through space further in his "¿Qué será de mí, cuytado?" (discussed above). This reading of "Cuytado" supports the view that in the composition can be seen a rift in the strictly gendered and hierarchical structures of late feudal society; "Cuytado" exposes these structures as artificial constructs whose laws are not the laws of desire at the level of the subject nor yet at the level of the political unconscious.

The focus on the female gaze is extended in the closing stanza of "Cuytado, qüando cuydo". The lyric persona's love sickness, depicted through the privation of eyes and senses, was such that others are imagined as appropriately reciting on his account Juan de Padilla's song, "Pues que siempre padesçî" (ID2565, SA7I79; Palacio, pp. I82-I83). The lover then directs the "Senyora" to read "aquesta antigua canción", arguing that if she were to read all of it, she would feel only a part of his own past affective experience. The injunction to the beloved to read in order to empathize with another's past experience creates a temporal sequence in which the lover's psychic states are emplotted affectively: his past suffering of his enamourment on account of her "oxos robadores", his present writing, others' future recitation of Padilla on his account, her hypothesized future affective reading of all of Padilla's "antigua canción" (1. 19) giving her only partial access to what he felt and provoking her compassion for his suffering that day: "lo que senti" (1. 24, my emphasis). Although his attenuated suffering is past, memory work of the total experience causes suffering in the present moment, "Cuytado, qüando cuydo" (l. I), since it involves an apprehension of his loss of self, and a reliving, a rekindling, of the intensity of his desire without release. The physical effects of the recollection manifest themselves through (presumably outward) signs, such as those of love sickness, which will cause others to identify him with Padilla's lyric persona.

Like "Cuytado", Padilla's song is also a direct address to the beloved in which the poet contemplates the suffering endured since he first saw her, "desque vos vi" (1. 2). Like Torres's poetic persona, the lover has done nothing to deserve such suffering. He fails to understand and evade his "loca maginança" (1. 9) and so serves the beloved loyally in the understanding that he can recover the good lost. In a reversal of this, Torres's lover contemplates the good that he receives from the "Senyora", dwelling on ("Quando he considerado [...]", 1. II) his own psychic and affective response. Padilla's lyric persona's state of mind, with his mental 
faculties playing obsessively on the beloved, is analogous to the psychic diminishment symbolized in the "Senyora"'s theft of the lover's eyes and senses, which is also his ability to apprehend and consider anything other than the beloved. Like Padilla's lyric persona, Torres's poetic subject also experiences attenuated and obsessive desire of amor hereos, his thought dwelling always on the object, which he considers has deprived him of his senses. In contrast, poised always on the verge of extreme psychic disarray, Padilla's lover depends on hope (and the affective resource of the song). Torres's locates his lover, however, as I suggested above, in a temporal sequence that casts the attempt to engage the beloved affectively in the perfective aspect through the use of temporal deixis and preterite verbal tense.

Torres's decir ventures further than Padilla's in other ways since it turns on a series of sightings. Torres's poetic persona presents himself as an (imagined) object of others' gazing: they see him and identify Padilla's song as an appropriate description of his physical and psychic disarray. The lover therefore exists in a public arena, with his external actions subject to others' judgement. His private experience, however, is public only in the sense that lyric is a public genre. In the courtly context of the first half of the fifteenth century, as expressed in the poetic prologues such as that of the Cancionero de Baena, Torres's lyric persona presents himself as every bit the ideal poet and lover; I shall return to this point shortly. ${ }^{43}$

The "Senyora", it is suggested, regards the lover, reads (or listens) to his decir, before being directed to Padilla's song, which is figured as an affectively transformative read text, not as sung performance. As such, "Pues que siempre padesçî" must be subject to the same process of intromission as the lover has been. The "Senyora" looks actively from a position of some power and has knowledge which those who compare the lyric persona and Padilla's lover lack. However, if her gaze has the power to entrap the lover by robbing him of his senses, he attempts to use its power to further his position by seeking continued emotional engagement with her not solely with his own words but with those of another.

Like the lover's heart and mind, and like "Cuytado, qüando cuydo" or "Sepas tú", Padilla's poem enters through Torres's "Senyora"'s eyes in the physical act of reading, before being intellectually apprehended and, the lover hopes, exciting an affective identification. Further by introducing the lady's hypothetical — that is, imagined - future response, Torres's lyric persona further locates the lady as a subject who, like him, is psychically constituted through sight and the scopic

${ }^{43}$ The Cancionero de Baena's prologue defends the view that the composition of poetry demonstrates courtly virtue and gains the subject status: see Folger (2002, p. 58, and 2009, pp. 59-60, 67). 
drive. Whilst "Cuytado, qüando cuydo" has a single implied recipient, "Pues que siempre padesçi" is presented as a good in public circulation. Torres's composition speaks of the dual status of both courtly love poetry and the look as at once purporting to be intimate private correspondence whilst simultaneously unfolding in a public space. Further, the comparison that the on-lookers make between Torres's and Padilla's lyric subjects levels their respective status: the two lovers are raised to the same standing and dignity and their amatory experience — despite differences - is presumed to be qualitatively equal. I take this to be an attempt on Torres's part to stake claim, through his poetic persona, to a higher poetic status than he might otherwise be perceived to enjoy. Torres projects his lover yet further since he no longer suffers in the same way as Padilla's does since his circulation of Padilla's lyric brings the supreme gift of projected recognition by the Other, which exists in fantasy only. The temporal emplotment of lyric action in "Cuytado" renders Torres's lover more successful in achieving the desired goal.

Stratification is present with regard to time, space and knowledge in the lyric. The beloved and the lover (and reader of the lyric) enjoy a privileged level of knowledge about the affair and the ironic contrast with Padilla's lover. Within the lyric world, there exist four spaces in the temporal emplotment in which visual perception is enacted, which reflect the flow of knowledge. First, the lover's recollection takes place in a present moment of lyric contemplation. Second, his recollection is of a private sphere in which occurred the sensory exchanges with the beloved "en aquel día"; the nature of the exchange is not made explicit but can be decoded through the operations of triple-entendre. Third, in the (imagined) future lyric public sphere, the court will observe the speaker of "Cuytado" and compare him to Padilla's lover. Finally, also in an imagined future, the beloved will become aware of this, perhaps through exposure to the lover's composition or through word of mouth and will read, therefore intromit (and perhaps also hold), Padilla's song. The lover implies that Padilla's song is sufficiently well known for the courtiers to recall it but that the lady may not yet be familiar with it. Torres thereby suggests the existence of two courtly spheres. The first is a presumably primarily homosocial space in which song circulates publicly and freely and functions as interpellation, bringing the subject into language and according status and recognition. The second is the private intersubjective domain in which it functions as private communication and in which the subject articulates the unanswerable desire to be seen and recognised by the Other.

In this article, I have discussed a number of Juan de Torres's love poems with a view to explicating the manner in which amatory experience is figured as simultaneously a private psychic experience and as public performance; what brings 
these two spheres into contact is their unfolding within a generalized visual sphere. I believe there are two intrinsic facets of such poetry that make this possible. The first is the inherently ambiguous nature of fifteenth-century courtly love poetry as being constructed as a genre dealing with the mediation between the subject's affect and the psychic, somatic and phenomenological world as represented in amatory experience. The second is related to the fact that court poetry of this type may at once (purport to) be private communication and for public reception and that each of these modes may be conceived of as oral or written. The private/public nature of amatory experience is thus translated into its transmission and reception modes.

The physical description of the beloved is redundant since her power, and its concomitant threat of pain / pleasure, is not organized in the visual —and has no relationship with nor bearing on the physicality of the object — but in the psychic, affective and somatic spheres whereby the subject's entry into the symbolic order is raised and maintained. It may be better to suggest that the visual sphere, rather, is the medium by and through which desire is apprehended and in which the subject constructs itself, seeks the desire of the Other and is subject to the surveying gaze of power hierarchies. Thus amatory encounters in courtly compositions unfold in the mind of the subject, in the private encounter between lover and beloved, and in public sphere as a claim to recognition. Yet making public amatory meditation and private address also exposes the fragmentation of the subject, which always seeks a means to shore up the fragmentary self, and shows the revolt of the political unconscious, which shudders in the presence of the laws against desire and trembles before the hierarchies of the name-of-the-Father within the symbolic order.

The lyric persona's experience of the shattered psychic state unfolds as much in the mind as it does within a(n imagined) hierarchically structured generalized visual sphere. The folding out into that same hierarchically structured generalized visual sphere of the dangers to the self emanating from sight and seeing also project the socially-constituted self into a space of permitted and barred looking wherein those who exercise power also exercise a surveying gaze and the very real power to punish transgressive looking and desire and to offer reward and confer recognition. ${ }^{44}$ As a consequence of the surveying gaze, secrecy and the control of knowledge become key practices in self-policing and in the poet's bid for courtly status. What Torres's courtly love lyric represses are the mechanisms whereby the

${ }^{44}$ On the surveying gaze see Foucault (1997, pp. 195-228, esp. pp. 200-203). 
lyric persona engages in a willing self-subjection to the demands of the law and the name-of-the-Father in an unequal society. The burgeoning (and excessive) success of cancionero lyric may speak to shared psychological shattering in the (re-)constitution of the subject as it passes through successive modes of production and yearns for a beyond — rather than a before - the symbolic order and its disciplining regimes; perhaps a similar psychological dislocation as that explored in the recent affective turn in cultural studies as it investigates depression as a public feeling in late capitalism. ${ }^{45}$

WORKS CITED

Agamben, G., 1993: Stanzas: Words, R. L. Martinez (trans.), Theory and History of Literature, 69, Minneapolis [I publ., 1977: Stanze: La parola e il fantasma nella cultura occidentale, Torino].

Beltrán, V., I999: "Tipología y génesis de los cancioneros: la organización de los materiales”, in V. Beltrán et al (ed.), Estudios sobre poesía de cancionero, Noia, pp. 9-54.

Berlant, L., 20II: Cruel Optimism, Durham (NC).

Berger, J., I973: Ways of Seeing. London.

Burke, J. F., 2000: Vision, the Gaze, and the Function of the Senses in "Celestina", University Park of Pennsylvania.

Burrus, V., 1998: "Role-Playing in the Amatory Poetry of the Cancioneros", in Poetry at Court in Trastamaran Spain from the "Cancionero de Baena" to the "Cancionero General", (ed. E. M. Gerli \& J. Weiss), Tempe, pp. III-33.

Cancionero de Palacio ms: Biblioteca de la Universidad de Salamanca, MS 2653; <http://gredos.usal.es/jspui/handle/I0366/8I629>.

Carruthers, M., 1990: The Book of Memory: A Study of Memory in Medieval Culture, Cambridge.

- 1998: The Craft of Thought: Meditation, Rhetoric, and the Making of Images 400-I200, Cambridge.

Casas Rigall, J., I995: Agudeza y retórica en la poesía amorosa de cancionero, Santiago de Compostela.

Cátedra, P. M., 1989: Amor y pedagogía en la Edad Media: estudios de doctrina amorosa y práctica literaria, Salamanca.

${ }^{45}$ See, for instance, Cvetkovich (20I2, esp. pp. 3-IO), and Berlant (2OII). 
CORDE, Corpus Diacrónico del Español, Real Academia Española, <http:// corpus.rae.es/cordenet.html., last consulted 24 May 20I6>.

Corominas, J., with J. A. Pascual, I991: Diccionario crítico etimológico castellano e hispánico, Madrid.

Crombie, A. C., I990: Science, Optics and Music in Medieval and Early Modern Thought, London.

Cvetkovich, A., 20I2: Depression: A Public Feeling, Durham (NC).

Dutton, B., et al., 1982: Catálogo-índice de la poesía cancioneril del siglo XV, Madison.

Dutton, B., with J. Krogstad, I990-9I: El cancionero del siglo XV, c. I360-I520, 7 vols, Salamanca.

Folger, R., 2002: Images in Mind: Love Sickness in Spanish Sentimental Fiction and 'Don Quijote', Chapel Hill.

- 2009: Escape from the Prison of Love: Caloric Identities and Writing Subjects in Fifteenth-Century Spain, Chapel Hill.

Fry, P., "Lecture I8: The Political Unconscious", Open Yale Course Introduction to Literary Theory, <http://oyc.yale.edu/english/engl-30o/lecture-I8, last consulted 24 May 20I6>.

Frye, N., 1957: The Anatomy of Criticism, Princeton.

Gatland, E., 20IO: “¿Qué me ha de aprovechar ver la pintura daquel que con las alas derretidas, cayendo, fama y nombre al mar ha dado?': Liminality in the Sonnets of Garcilaso de la Vega”, Forum for Modern Language Studies, 47, pp. I-I7.

Gaunt, S., 200I: "Martyr to Love: Sacrificial Desire in the Poetry of Bernard de Ventadorn", Journal of Medieval and Early Modern Studies, 3I, pp. 477-506, $<$ https://muse.jhu.edu/article/ı6496>.

— 2004: "The Look of Love: The Gender of the Gaze in Troubadour Lyric", in E. Campbell \& R. Mills (eds.), Troubled Vision: Gender, Sexuality, and Sight in Medieval Text and Image, New York, pp. 79-95.

Gerli, E. M., 2000: "Leriano and Lacan: The Mythological and Psychoanalytical Underpinnings of Leriano's Last Drink", La corónica, 29.I, pp. II3-28.

- 20II: Celestina and the Ends of Desire, Toronto.

Green, C. D., 2003: "Where Did the Ventricular Localization of Mental Faculties Come From?", Journal of the History of the Behavioral Sciences, 39, pp. I3I-I42.

Hardt, M., \& K. Weeks, 20oo: "Introduction”, The Jameson Reader, Oxford, pp. I-30.

Haywood, L. M., 2008: Sex, Scandal and Sermon in Fourteenth-century Spain: Juan Ruiz's "Libro de Buen Amor", New York. 
- 2009: "Juan de Torres in the Context of the Cancionero de Palacio", Bulletin of Hispanic Studies, 86 (Late Medieval Spanish Studies in Honour of Dorothy Sherman Severin, ed. J. T. Snow and R. Wright), pp. 46-54.

Holsinger, B., 2005: The Premodern Condition: Medievalism and the Making of Theory, Chicago.

Jameson, F., 1989: The Political Unconscious: Narrative as a Socially Symbolic Act, London. [I ${ }^{\text {st }}$ publ. $198 \mathrm{I}$ ]

Kay, S., 200I: Courtly Contradictions: The Emergence of the Literary Object in the Twelfth Century, Stanford.

Klassen, N., 1995: Chaucer on Love, Knowledge, and Sight, Cambridge.

Lacan, J., 1993: "Courtly Love as Anamorphosis", in J.-A. Miller (ed.), D. Porter (trans.), Seminar of Jacques Lacan: VII, The Ethics of Psychoanalysis, I959-60, London, pp. 139-I54.

Lacan, J., 2004: The Four Fundamental Concepts of Psycho-analysis, J.-A. Miller (ed.), A. Sheridan (trans.), London. [I' . publ. 1973, Paris]

Macpherson, I., 1985: "Secret Language in the Cancioneros: Some Courtly Codes", Bulletin of Hispanic Studies, 62, pp. 5I-64.

Mosquera Novoa, L., 2015: "Juan de Torres: edición y estudio de su poesía", doctoral dissertation, Universidade da Coruña, <http://ruc.udc.es/dspace/ bitstream/handle/2183/15935/MosqueraNovoa_Lucia_TD_2015_resumido. pdf? sequence $=2 \&$ isAllowed $=y$, last consulted 24 May 20I6> .

Palacio, Cancionero de, 1993: A. M. Álvarez Pellitero (ed.), Cancionero de Palacio, ms. 2653, Biblioteca Universitaria de Salamanca, Salamanca.

Rodado Ruiz, A. M., 2000: "Tristura conmigo va": fundamentos del amor cortés, Cuenca.

Sedgwick, E. K., 1985: Between Men and Male Homosocial Desire, New York.

Spearing, A. C., 1993: The Medieval Poet as Voyeur: Looking and Listening in Medieval Love-Narratives, Cambridge.

Tascioglu A. O., \& A. B. Tascioglu, 2005: "Ventricular Anatomy", Neuroanato$m y, 4$, pp. 57-63.

Tillier, J. Y., 1985: "Passion Poetry in the Cancionero", Bulletin of Hispanic Studies, 62, pp. 65-78.

Toro Pascua, M. I., I994: "Guevara y la teoría amorosa en el reinado de Enrique IV", in Actas del III Congreso de la Asociación Hispánica de Literatura Medieval (Salamanca, 3 al 6 de octubre de 1989), Salamanca, I994, vol. II, pp. I085IO93.

Vendrell de Millás, F., 1945: El cancionero de Palacio: manuscrito no. 594, Barcelona. 
Wack, M. F., I990: Lovesickness in the Middle Ages The 'Viaticum' and Its Commentaries, Philadelphia.

Whinnom, K., 1981: La poesía amatoria cancioneril en la época de los reyes católicos, Durham.

Žižek, S., I994: "Courtly Love, or, Woman as Thing", in The Metastases of Enjoyment: Sex Essays on Woman and Enjoyment, London: Verso, pp. 89-II2. [Reprinted with an explanatory introduction in E. Wright \& E. Wright (eds.), 1999: The Žižek Reader, Oxford, pp. I48-173. 